\title{
Research on Climate - Grapevine Yield Relationship and the Impact of Global Warming
}

\author{
Georgeta Mihaela BUCUR ${ }^{1}$, Liviu DEJEU ${ }^{1 *}$ \\ ${ }^{1)}$ Department of Horticultural Bioengineering Systems, University of Agronomic Sciences and Veteri- \\ nary Medicine, Bucharest, Romania. \\ ${ }^{*}$ Coresponding author, e-mail: liviudejeu@gmail.com
}

Bulletin UASVM Horticulture 71(2) / 2014

Print ISSN 1843-5254, Electronic ISSN 1843-5394

DOI:10.15835/buasvmcn-hort:10402

\begin{abstract}
Trends of climate variables were studied for the latest 41 years (1973-2013) and their effects on the quantity and quality of the grape production for Feteasca regala variety, clone $21 \mathrm{Bl}$, grafted on Kober $5 \mathrm{BB}$, in the plantation of the University of Agricultural Sciences and Veterinary Medicine, Bucharest, for the latest 16 years (1998-2013). Following the trend of main climate variables, there was a highly significant heating, especially in the summer. Some significant correlations were established between climate variables and production, sugar accumulation in the berries and titratable acidity in the must. Significant results were obtained with bioclimatic indices Huglin and Winkler. It also increased the number of hot days (with maximum temperature above $30^{\circ} \mathrm{C}$ ) and very hot days (with maximum temperature above $35^{\circ} \mathrm{C}$ ), which adversely affects the metabolism of vines, producing unbalanced wines. Since it is expected that this trend of temperature rising continues in the future and that the ripening period of the grapes takes place in warmer conditions, there are necessary adjustments of viticulture development strategies under the new conditions.
\end{abstract}

Keywords: grapevine, climate change, yield

Introduction. Global warming from the latest years has been favourable for grapevine growing and for berries ripening. Grapes composition changes, leading among other things, to a high sugar content, a decrease in acidity and it inevitably affects wine typicity (Cotea et al., 2008; Carbonneau, 2011; Bucur et al., 2012).

Aims and objectives. The aim of this paper is to determine the trends of climate change in the latest 41 years and their effect on vine between 1998 and 2013.

Materials and methods. The climatic data were obtained for a period of 41 years (19732013), for Bucharest meteorological station ( $\left.44^{\circ} 47^{\prime} \mathrm{N} ; 26^{\circ} 07^{\prime} \mathrm{E}\right)$, in order to calculate minimum, maximum and average temperature, the number of days with very hot $\left(\operatorname{Tmax}>35^{\circ} \mathrm{C}\right.$ ) and hot (Tmax $>30^{\circ} \mathrm{C}$ ) temperature, Huglin Index, Winkler Index in the growing season and in different periods of the year. It was followed their evolution in time and there were settled correlations between these parameters and grape production, accumulation of sugars in the berries, grape acidity in clone 21 $\mathrm{Bl}$ Feteasca regala cultivar, at the experimental plantation of the University of Agricultural Sciences and Veterinary Medicine Bucharest, in the period 1998-2013.

Results and discussion. It has been found a highly significant trend of increasing average temperature during the growing season (IV-X), especially in the summer (VI-VIII) (Tab.1). At the same time, there was a highly significant increase in the number of hot days (with $\operatorname{Tmax}>30^{\circ} \mathrm{C}$ ) and very hot days (with $\operatorname{Tmax}>35^{\circ} \mathrm{C}$ ), associated with more frequent heat waves during ripening. The same high level of significance was obtained in terms of increasing trends of annual maximum and average temperatures of the warmest month of the year (July), unlike the average minimum temperature in January (not significant variations). Highly significant increasing trends were also found, in time, for bioclimatic indices Huglin and Winkler. There have been established correlations between climate variables and grapes 
Tab.1 Trends of some climate variables in different periods of the year (Bucharest, 1973-2013)

\begin{tabular}{ccccccc}
\hline Variable & $\begin{array}{c}\text { Period of the } \\
\text { year }\end{array}$ & $\begin{array}{c}\text { Signi- } \\
\text { ficance }\end{array}$ & $\begin{array}{c}\text { Decadal } \\
\text { trend }\end{array}$ & Average & Maximum & Minimum \\
\hline Average temperature $\left({ }^{\circ} \mathrm{C}\right)$ & I-XII & $* *$ & 0.31 & 11.4 & 13.4 & 10.2 \\
\cline { 2 - 7 } & IV-X & $* * *$ & 0.37 & 17.9 & 19.8 & 16.4 \\
\cline { 2 - 7 } & XII-II & NS & 0.12 & 0.1 & 4.0 & -4.3 \\
\cline { 2 - 7 } & III-V & NS & 0.24 & 11.7 & 13.8 & 8.5 \\
\cline { 2 - 7 } & VI-VIII & $* * *$ & 0.63 & 22.2 & 25.3 & 19.9 \\
\cline { 2 - 7 } & IX-XI & NS & 0.21 & 11.7 & 13.8 & 9.5 \\
\hline No of days with Tmax $>35^{\circ} \mathrm{C}$ & V-IX & $* * *$ & 2.70 & 5.8 & 28.0 & 0.0 \\
\hline No of days with Tmax $>30^{\circ} \mathrm{C}$ & V-IX & $* * *$ & 9.00 & 43.7 & 79.0 & 14.0 \\
\hline Average annual Tmax $\left({ }^{\circ} \mathrm{C}\right)$ & I-XII & $* * *$ & 0.48 & 16.9 & 19.2 & 15.0 \\
\hline Average Tmax in July $\left({ }^{\circ} \mathrm{C}\right)$ & VII & $* * *$ & 0.90 & 29.5 & 34.9 & 25.6 \\
\hline Average Tmin in January $\left({ }^{\circ} \mathrm{C}\right)$ & I & NS & -0.10 & -5.3 & -1.2 & -11.8 \\
\hline Huglin Index $\left({ }^{\circ} \mathrm{C}\right)$ & IV-IX & $* * *$ & 100 & 2265 & 2734 & 1942 \\
\hline Winkler Index $(\operatorname{degree~days)~}$ & IV-X & $* * *$ & 74 & 1573 & 2042 & 1243 \\
\hline
\end{tabular}

Tab. 2 Correlations between some climate indicators, production and its quality

\begin{tabular}{|c|c|c|}
\hline Variable & $\begin{array}{l}\text { Signifi- } \\
\text { cance }\end{array}$ & $\begin{array}{c}\text { Correlation } \\
\text { coefficient }\end{array}$ \\
\hline Average maximum temperature in July $\left({ }^{\circ} \mathrm{C}\right)-\operatorname{sugar}(\mathrm{g} / \mathrm{L})$ & NS & 0.266 \\
\hline Average maximum temperature in July $\left({ }^{\circ} \mathrm{C}\right)$ - titratable acidity $\left(\mathrm{g} / \mathrm{L} \mathrm{H}_{2} \mathrm{SO}_{4}\right)$ & * & 0.520 \\
\hline No of days with $\operatorname{Tmax}>30^{\circ} \mathrm{C}-\operatorname{sugar}(\mathrm{g} / \mathrm{L})$ & NS & 0.371 \\
\hline No of days with $\mathrm{Tmax}>30^{\circ} \mathrm{C}$ - titratable acidity $\left(\mathrm{g} / \mathrm{L} \mathrm{H}_{2} \mathrm{SO}_{4}\right)$ & $* *$ & 0.636 \\
\hline Precipitations (III-V) - production (kg/vine) & * & 0.590 \\
\hline Huglin Index $\left({ }^{\circ} \mathrm{C}\right)-$ production $(\mathrm{kg} / \mathrm{vine})$ & NS & 0.285 \\
\hline Huglin Index $\left({ }^{\circ} \mathrm{C}\right)-\operatorname{sugar}(\mathrm{g} / \mathrm{L})$ & * & 0.512 \\
\hline Huglin Index $\left({ }^{\circ} \mathrm{C}\right)$ - titratable acidity $\left(\mathrm{g} / \mathrm{L} \mathrm{H}_{2} \mathrm{SO}_{4}\right)$ & ** & 0.629 \\
\hline Winkler Index (degree days) - production (kg/vine) & NS & 0.395 \\
\hline Winkler Index (degree days) - sugar (g/L) & $*$ & 0.503 \\
\hline Winkler Index (degree days) - titratable acidity $\left(\mathrm{g} / \mathrm{L} \mathrm{H}_{2} \mathrm{SO}_{4}\right.$ ) & NS & 0.454 \\
\hline
\end{tabular}

production for Feteasca regala, during 1998-2013, the accumulation of sugars in the grape berries and titratable acidity from the must (Tab.2). Distinctly significant correlations were identified between the number of days with Tmax above $30^{\circ} \mathrm{C}$ and titratable acidity of the grape, and between Huglin index and the same variable quality.

Conclusion. In the last decade, there was a highly significant increasing trend of the temperature during the growing season, more evident for the summer. The documented effects of the historical trends and their influence on the vine are a valuable indicator of what could be expected in the future, highlighting the need to implement measures of adaptation to these climate changes.

\section{REFERENCES}

1. Bucur GM, Dejeu L, Cazan G, Tănase A (2012). Researches concerning the influences of climate changes on grapevine. Sci Pap U.S.A.M.V. Bucharest, B, LVI:43-47.

2. Carbonneau A (2011). Quelques idées de stratégies viticoles face au changement climatique. Progr Agric Vitic, Montpellier, 128 (15/16):301-305.

3. Cotea VV, Rotaru L, Irimia LM, Colibaba C, Tudose Sandu - Ville S (2008). The grean house effect on the viticultural ecoclimat in Northern Moldavia, Romania. 31st World Congress of Vine and Wine, Verona, Italy.

4. Huglin P (1978). Nouveau mode d'évaluation des possibilités héliothermiques d'un milieu viticole. In: Symp Intern Écologie de la Vigne, Constanta, Roumanie:89-98.

5. Winkler AJ, Cook A, Kliewer WM, Lider IA (1974). General Viticulture University of California Press, Berkeley, 740p. 